\title{
Effects of Trunk Control Rehabilitation Robot Training on Dynamic Balance, Lower Extremity Strength, Gait Ability and Pain in Bipolar Hemiarthroplasty
}

HyunKwan Yang', Hyoungwon Lim²

'Department of Physical Therapy, Graduate school, Dankook University; ${ }^{2}$ Department of Physical Therapy, Dankook University, Cheonan, Korea

Purpose: This study examined the effects of trunk control rehabilitation robot training (TCRRT) on the dynamic balance, lower extremity strength, gait ability and pain for bipolar hemiarthroplasty.

Methods: Hemiarthroplasty $(n=28)$ patients participated in this study. The subjects were randomized into two groups: trunk control rehabilitation robot training group and control group.

Results: The TCRRT group showed significantly more improvement in the MFRT, MMT, 10MWT, TUG, and VAS compared to that before intervention ( $<$ 0.05). In addition, all tests were significantly greater in the experimental group than in the control group.

Conclusion: These results suggest that TCRRT is feasible and effective for improving the dynamic balance, lower extremity strength, gait ability, and pain efficacy after bipolar hemiarthroplasty.

Keywords: Bipolar Hemiarthroplasty, Gait Ability, Dynamic Balance, Trunk Control Rehabilitation Robot Training, Lower Extremity Strength

서 론

$\mathrm{WHO}$ 는 매년 646,000건의 치명적인 낙상이 발생한다고 하였으며, 교 통사고 이외 비의도적으로 발생하는 부상의 두 번째로 사망의 주된 요인이라고 하였다. 이러한 노인 인구에서 낙상은 신체적 손상으로 일상생활의 장애와삶의 질을 떨어 뜨린다. ${ }^{1}$

노인 인구에서 낙상으로 인한 골절은 $50 \%$ 이상이 엉덩관절 골절 로 나타났고, 그 발생률은 2050년에 현재의 두 배가 될 것으로 추정 된다. 우리나라에서도 노인의 엉덩관절 골절 발생률이 급격하게 증 가하고 있으며, ${ }^{3}$ 나이가 많은 노인일수록 근육량의 감소와 골밀도의 저하를 가지고 있으며, 낙상 발생 시 넙다리뼈 목 골절과 넙다리뼈돌 기사이 골절이 가장 흔하게 발생한다. ${ }^{4}$ 양극성 인공관절 부분치환술 (bipolar hemiarthroplasty)은 노인의 근위부넙다리뼈 골절(넙다리뼈 목 골절 및 넙다리뼈돌기사이 골절)에 보편적인 수술 방법이며, ${ }^{5}$ 주로 골절 부위의 전위가 심한 환자에게 사용된다. ${ }^{5}$ 이러한, 성공적인 수술 에도 불구하고 양극성 인공관절 부분치환술 후 하지 근력의 비대칭 적인 약화와 체중지지의 불균형으로 인하여 균형 능력의 감소로 절
뚝거림 등 비정상적인 보행으로 움직임의 제한을 갖게 된다. ${ }^{6}$ 일반적 으로 엉덩관절 수술 후 대부분의 환자들은 엉덩관절의 폄근과 굽힘 근의 약화뿐만 아니라 벌림근의 근 약화를 보이며, 비수술 측 하지의 과도한 체중지지는 수술 측 하지의 근력 감소를 보상하려고 하기 때 문이다. 인공무릎관절 전치환술 환자의 경우에서도 동일한 결과인 비대칭적 체중지지를 나타냈으며 이것은 비수술 측 엉덩관절에 많은 체중지지를 유발하는 원인이 된다. ${ }^{8}$ Miura 등 ${ }^{9}$ 의 연구에 따르면 인공 관절 전치환술 환자에서 앉았다 일어서기 동작 시 수술 측 하지의 낮 은 체중 부하를 보고하였으며 이것은 수술 후 1 년이 경과되어도 지속 적인 문제로 남는다고 하였다. 또한, Sumaye 등 ${ }^{10}$ 의 연구에서는 인공 관절 전치환술 후 STS 움직임 시 수술 측 하지의 작은 모멘트 및 지면 반발력은 수술 측 하지의 균형 조절의 문제점을 보고하였고, ${ }^{11}$ 이러 한 문제는 수술 후 1년이 경과되어도 지속적인 문제로 남는다고 하였 다. ${ }^{6}$

최근 과학기술의 발달과 4 차 산업 혁명 시대로의 진입을 통해 로 봇을 이용한 물리치료가 임상에서 시범적으로 적용되고 있다. 이러 한 체간보정재활로봇 훈련은 노인의 조기 물리치료에 도움이 되며,
Received Mar 18, 2019 Revised Apr 16, 2019

Accepted Apr 19, 2019

Corresponding author Hyoungwon Lim

E-mail movt12@hanmail.net
Copylight (C2019 The Korean Society of Physical Therapy

This is an Open Access article distribute under the terms of the Creative Commons Attribution Non-commercial License (Http:// creativecommons.org/license/by-nc/4.0.) which permits unrestricted non-commercial use, distribution, and reproduction in any medium, provided the original work is properly cited. 
신체적 손상 시 체간보정재활로봇 훈련을 통해 기능적 움직임을 향 상시키고 빠른 회복과 독립적인 생활을 가능하게 할 수 있다. ${ }^{12}$ 또한, 시 · 지각적 바이오피드백을 이용한 로봇 보조 물리치료는 정확하고 일관적인 치료를 제공하여 환자의 능동적인 참여로 동기 유발과 함 께 기능적 움직임을 촉진한다. ${ }^{13}$ 본 연구에 적용된 체간보정재활로봇 훈련은 난이도가 있는 과제 구성으로 지속적으로 수술 측 하지에 체 중 부하와 체중 이동 훈련이 가능하게 도와주며 운동수행에 필요한 감각 되먹임을 제공하여 균형 능력의 향상, 체간 안정성 및 하지 근력 을 강화하여 보행 능력을 개선하는데 효과적인 운동방법이라고 하 였다. ${ }^{14}$ 또한, 체간 조절 향상과 앉은 자세 균형, 보행 및 일상생활 동작 과 매우 유의한 관련성이 있고 기능적인 예후를 결정짓는 변수로 체 간재활운동의 중요성을 강조하고 있다. ${ }^{15}$

로봇치료의 선행연구로는 운동 실조증 환자를 대상으로 일상생활 의 기능적 자립력과 균형 및 협응의 개선을 보고 하였다. ${ }^{16}$ 또한 아급 성 및 만성 뇌졸중 환자를 대상으로 착용 가능한 외골격계 로봇 (wearable robotic exoskeleton)을 이용한 보행 훈련의 효과와 척수손상, 뇌성마비 및 진행성 다발성경화증 환자에게 로봇 보행 훈련의 다양 한 효과를 보고하였다. 이처럼 대다수의 이전 연구들은 대부분 신경 계 질환에 로봇-보조보행 훈련을 적용하였으며 엉덩관절 골절 등으 로 인한 양극성 인공관절 부분치환술(bipolar hemiarthroplasty)을 한 환자에게 체간보정재활로봇 훈련을 적용한 사례는 전무한 실정이다. 따라서 본 연구는 체간보정재활로봇 훈련이 양극성 인공관절 부분 치환술(bipolar hemiarthroplasty) 후 동적 균형, 하지 근력, 보행 능력 및 통증에 미치는 영향을 조사함으로써 체간보정재활로봇 훈련의 유용성을 확인하고 이후 체간보정재활로봇 훈련을 이용한 물리치료 중재에 대한 근거를 제공하고자 한다.

\section{연구 방법}

\section{1. 연구대상}

본 연구는 충청남도 천안시 $\mathrm{D}$ 대학교 의과대학부속병원 재활의학과 에 입원 중인 65 세 이상 노인 환자 28 명을 대상으로 실시하였으며, 실 험에 참여한 환자 및 보호자에게 연구의 목적과 실험방법에 대하여 설명하고 동의를 구하였다. 연구 대상자의 선정 조건은 첫째, 양극성 인공관절 부분치환술 수술 환자. 둘째, 한국형 간이 정신 상태 판별 검사(mini mental state examination korea version, MMSE-K)점수가 24 점 이상으로 인지 기능의 장애가 없다고 판별된 환자. 셋째, 보조 기 구를 사용 유무에 관계없이 30 초 이상 서기가 가능한 환자. 넷째, 보 행기를 이용해 $10 \mathrm{~m}$ 보행이 가능한 환자. 넷째, 시야 결손과 전정기관 에 이상이 없는 환자로 선정하였다.

\section{2. 실험방법}

\section{1) 실험절차}

본 연구 설계는 무작위 대조 연구(randomized controlled trial, RCT)로 진행되었으며, 대상자 선정 후 동질성 검정을 하였고, 난수표를 이용 하여 두 집단으로 무작위 할당하였다.

본 연구에서 양극성 인공관절 부분치환술(bipolar hemiarthroplasty) 수술을 한 후 3 일간 침상안정을 취하였다. 모든 중재는 3 주 동안 총 18 일간 진행 되었으며, 급성기 환자의 기준선을 설정하기 위하여 3 일간(2회/하루) 기준선(baseline) 설정 중재 운동(경사침대훈련, 관절 가동범위 확보, 독립적 앉기와 보행기 보행)을 수행하여 선정하였다. 이후 실험군과 대조군으로 분류하여 각각 총 15 일간(1회/하루) 연구 하였으며, 본 연구의 평가는 중재 전과 중재 기간(15일) 동안 매5회(5 회, 10 회, 15 회) 마다 각각의 검사 항목에 대하여 3 회씩 평가하여 평균 값을 얻었다. 중재 중 환자가 불편함을 호소하거나 중재를 거부 할 경 우즉각적으로 적용을 중지하였다

먼저 치료 집단을 중재 방법에 따라 일반적인 물리치료를 적용한 일반적인 물리치료군(conventional group: $\mathrm{CG}, \mathrm{n}=14$ )을 대조군으로, 체간보정재활로봇 훈련을 적용한 체간보정재활로봇 훈련군(trunk control rehabilitation robot training group: TCRRTG, $n=14$ )을 실험군으 로 하였다. 중재 전 모든 대상자에게 동적 균형, 하지 근력, 보행 능력 및 통증을 검사하였다. 대조군은 엉덩관절 운동치료 프로그램 20 분 적용과 보행기(walker) 보행을 15 분 추가하여 전체 치료시간을 35 분 으로 하였으며, 실험군은 엉덩관절 운동치료 프로그램 20 분 적용 후 체간보정재활로봇 훈련을 추가로 15 분간 적용하여 총 치료시간은 35 분으로 하였다.

\section{2) 연구 방법}

실험군과 대조군은 대상자 블라인드를 위해서 각각 시간대를 달리 하여 실험에 참가하였다. 본 연구에서는 환자의 안전사고 예방을 위 해 연구 보조자 1 명을 두고 진행하였다.

\section{(1) 기준선 설정을 위한 운동치료}

수술 직후 1-3일 동안(2번/하루, 35 분) 경사 테이블(tilt table) 15 분을 적 용하여 기립성 저혈압 예방과 관절가동범위의 확보를 위해 부드러운 수동 관절운동을 실시하였다. 연구자는 이를 통해 엉덩관절의 관절 가동범위는 $90-100^{\circ}$ 를 확보하도록 하였으며 1 분 이상의 독립적 앉기 와 서기 및 보행기(walker)를 사용하여 $10 \mathrm{~m}$ 보행이 가능하도록 하였 다. 이 시점을 기준선으로 설정하여 각각 실험군과 대조군으로 무작 위할당하였다. 
(2) 인공 엉덩관절 운동치료 프로그램 치료 중재 방법(공통)

운동방법은 Rampazo-Lacativa, D'Elboux ${ }^{17,18}$ 의 운동치료를 노인의 운 동 능력에 맞게 시간을 수정하여 10가지 운동(deep breathing exercise, ankle pumps exercise, gluteal squeeze exercise, static quads exercise, ROM exercise, heel slide exercise, long arc quadriceps active exercise, active of hip flx/ext/abd exercise)와 보행을 적용하였다. 운동의 종류는 이완 운 동, 등척성 운동 및 신장(stretch) 운동, 관절가동범위(ROM) 운동, 그 리고 보행기(walker) 보행 운동을 실시하였다. 공통 인공관절 운동치 료 훈련 프로그램은 다음과 같다.

(3) 체간보정재활로봇훈련(trunk control rehabilitation robot training,

TCRRT)군의 중재 방법

실험군은 엉덩관절 운동프로그램(20분)에 추가적으로 체간보정재활 로봇(15분)를 적용하여 총 35 분을 15 회 적용한다. 체간보정재활로봇 (trunk control rehabilitation robot, 3DBT-33, Man and tel, Gumi, Korea) 은 재활 로봇 보급 사업단에서 제작하여 식품의약품 안전처으로부 터 허가받은 기기(제14-1174호)로 시각적으로 모니터(visual feedback)
를 보면서 게임을 통한 체간 안정화 훈련 및 체중이동 훈련을 할 수 있고, 전동 로봇 팔 기능과 로봇 틸팅 의자(tilting chair) 기능을 이용하 여 앉았다 일어서기(sit to stand)와 체간의 앞, 뒤, 왼쪽, 오른쪽, 돌림 동작을 훈련시키는 기기이다. 구성은 앞면에 모니터가 있으며 일어설 때 당겨주는 전동 로봇 팔과 엉덩이 왼쪽과 오른쪽에 무게 센서 (weight sensor)가 있어 양측 무게를 감지하고 앉은 상태에서 일어서기 가 가능하도록 구성되어 있다. 본 연구에서 체간보정재활로봇 훈련 은 내재된 프로그램으로 모니터를 보며 앉은 자세에서 체중이동 훈 련(weight shift in sitting) 3 분, 앉았다 일어서기(sit to stand) 훈련 9분 및 선 자세에서 체중이동 훈련(weight shift in standing) 3 분으로 3 가지의 프로그램을 순서대로 환자에게 적용하였다(figure 1)(Table 1).

\section{3) 측정도구 \\ (1)동적 균형 검사}

동적 균형 평가는 수정된 기능적 팔 뻗기 검사(modified functional reach test, MFRT) 로 평가 하였다. ${ }^{19}$ 수정된 기능적 팔 뻗기 검사는 환 자의 우세 측 팔로 지팡이를 잡고 지팡이 아래 체중계를 사용하여 체
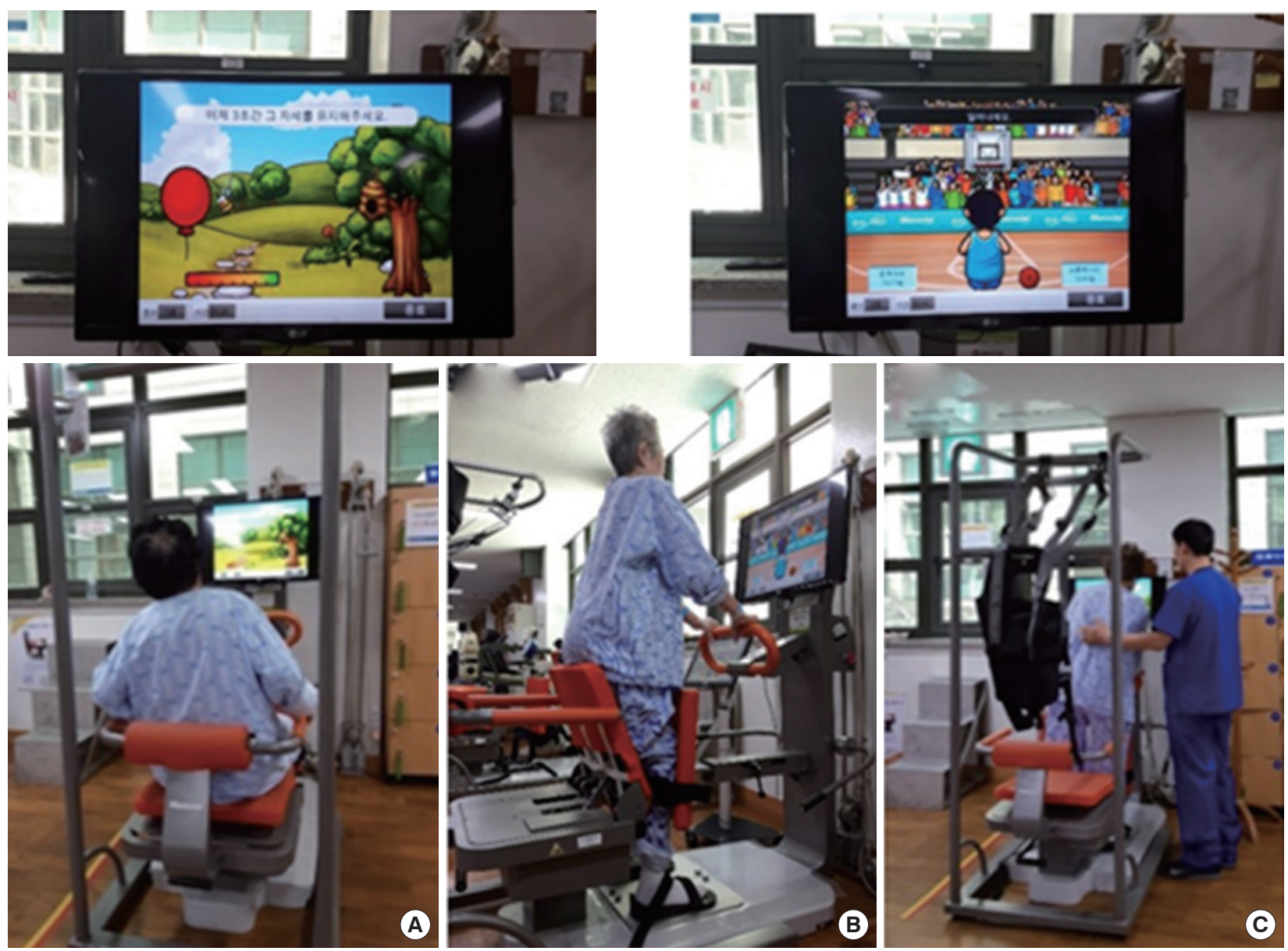

Figure 1. Trunk control rehabilitation robot training. A: weight shifting sitting, B: sit to stand, C: weight shifting standing 
중의 $10 \%$ 이내의 체중지지만을 허용하였고, $10 \%$ 를 초과하면 측정값 은 누락시켰고 다시 측정하였다. 환자는 벽에 기대지 않고 어깨관절 을 90도 굽힘과 팔꿉 관절을 완전히 폄 상태로 주먹을 쥐고 세 번째 손허리뼈(metacarpal bone head)의 끝을 시작점을 표시하고, 발뒤꿈치 를 떼지 않고 손을 앞으로 평평하게 뻗도록 지시하고, 10 초 동안 유지 할 수 있는 지점에 표시하여 준비 자세와 차이를 $\mathrm{cm}$ 단위로 측정 기 록 한다. ${ }^{19}$ 이와 같은 방법으로 3 회 반복 실시하여 그 평균값을 측정값 으로 결정하였다.

\section{(2) 하지근력검사}

근력 측정 장비는 Lafayette manual muscle test system (Model 01163, Lafayette Instruments, Lafayette, IN, USA)를 사용하여 근력을 평가하였다. 휴대용 근력 측정기의 신뢰도는 ICC $=0.84-0.99$ 로 높게 보고 되었다. ${ }^{20}$ 모든 측정은 하지 근력을 알아보기 위하여 하지 각 근육에 대하여 휴 대용 근력 측정기로 측정하였고 환자에게 충분한 사전 설명을 한 후에 검사하였다. 대상자들은 측정 자세를 취하고 보상작용을 막기 위해 벨 트로 고정하였다. 측정은 비 수술 측 하지를 먼저 검사를 한수 수술 측
하지의 엉덩관절 굽힘근, 폄근, 벌림근과 무릎관절 굽힘근을(Table 2) 과 같이 표준화된 자세에서21-23 측정하고 단위는 $\mathrm{kg}$ 으로 표시하였다.

측정하기 이전에 1-2회 익숙화 과정을 실시 후 3회 최대 등척성 수 축을 하도록 지시하였다. 측정 시작과 함께 환자들에게 "가능한 한 빠르고 최대의 힘”을 주도록 구두 지시를 하였다. 5 초의 수축 기간이 수행되고, 각각의 운동에 대해 3회 측정하여(maximal voluntary isometric contraction, $\mathrm{MVC}$ )로 기록하고 평균값으로 기록하였다. 각 측 정마다 근 피로를 막기 위해 30 초의 휴식을 가졌 다. ${ }^{24}$ 평가는 중재 전 과 중재 후(5회, 10회, 15회)에 양측 다리 모두 평가하였다.

(3) $10 \mathrm{~m}$ 보행검사(10meter walk test, 10MWT) $10 \mathrm{M}$ 보행 검사는 직선 보행 능력을 평가하기 위한 검사이다. 총 $14 \mathrm{~m}$ 를 최고 속도로 걷게 하고 처음 $2 \mathrm{~m}$ 와 마지막 $2 \mathrm{~m}$ 는 가속기와 감속기 로 측정에서 제외한다. 중간 $10 \mathrm{~m}$ 의 거리에 대한 보행 시간을 스톱워 치로 보행 시간을 측정하였다. 초기 연습 시험은 2 회 시험 시행하고 시험 사이 1 분간의 휴식을 가졌다. $10 \mathrm{M}$ 보행 검사를 3 회 실시하여 평 균값을 사용하였다. 보행 속도 단위는 초(sec)로 기록하였다. 이 검사

Table 1. Trunk control rehabilitation training program

\begin{tabular}{|c|c|c|}
\hline Variety & $\begin{array}{l}\text { Time } \\
\text { (15min) }\end{array}$ & Description \\
\hline $\begin{array}{l}\text { Weight shift in sitting/ } \\
\text { weight shift in standing }\end{array}$ & $6 \min$ & $\begin{array}{l}\text { A. A game in which a score is increased if a bee flies on the screen and explode a balloon. (weight shift training to sugucal site) } \\
\text { B. When weight the left and right weights, when the reaches the target value, the bee flies to the balloon and keeps the weight } \\
\text { for the set holding time, the bee fires and bursts the ballon. } \\
\text { C. You can check the score and the time you have gained during the traing. }\end{array}$ \\
\hline Sit to stand & $9 \min$ & $\begin{array}{l}\text { A. A game in which the score of the basketball entering the goal is increased while keeping the left and right balance of the } \\
\text { trunk. } \\
\text { B. The left arm and right arm balance of the trunk keeps 50:50, and the robot arm that can stand up to the front is coming for- } \\
\text { ward. When you give your legs power to hold and stand, the robot tilting chair is driven so that it can rise, and the robotic } \\
\text { arm pulls, so that you can repeat the sitting and standing motion repeatedly. } \\
\text { C. You can check the score and the time you have gained during the training. }\end{array}$ \\
\hline
\end{tabular}

Table 2. Lower limb strength measurement method

\begin{tabular}{|c|c|c|}
\hline Experimental task & Muscle strength measurement posture & position \\
\hline Hip joint flexion & $\begin{array}{l}\text { Take a sitting position on a backrest chair with armrests. Both hands are placed in a relaxed po- } \\
\text { sition on the armrest and the pelvis is secured with a strap for the accuracy of the strength } \\
\text { measurement.. The hip and knee joints have a } 90 \text { degree angle and ankles take a neutral po- } \\
\text { sition away from the ground. }{ }^{21}\end{array}$ & $\begin{array}{l}\text { The front of the femur bone, the upper edge } \\
\text { of the patella bone } 5 \mathrm{~cm} \text { is located on the } \\
\text { body side. }\end{array}$ \\
\hline Hip joint extension & $\begin{array}{l}\text { Take a lying position immediately on the therapeutic bed. In order to prevent the stability of the } \\
\text { pelvis and the back of the lumbar spine, the pelvis is fixed with a strap. The hip and knee joint } \\
\text { is } 90 \text { degrees and ankle joint is measured with resistance to the proximal to popliteal crease } \\
\text { do. }{ }^{22}\end{array}$ & $\begin{array}{l}\text { It is located on the proximal to popliteal } \\
\text { crease. }\end{array}$ \\
\hline Hip joint abduction & $\begin{array}{l}\text { Take a supine immediately in the therapeutic bed. Stability of the pelvis and lumbar spine to } \\
\text { prevent forward banding, the pelvis is fixed with a strap, and the hip joint abduction is mea- } \\
\text { sured in full extension and ankle joint neutralization of the hip and knee joint. }{ }^{23}\end{array}$ & $\begin{array}{l}\text { It is located on the side of the femur bone, on } \\
\text { the lower end of the body. }\end{array}$ \\
\hline Knee joint flexion & $\begin{array}{l}\text { Take a seat on the chair with the backrest and the subject puts his hands comfortably on the } \\
\text { armrest. } \\
\text { Using the strap, the pelvis is fixed to the chair, and the foot is measured at } 90 \text { degrees of the } \\
\text { hips and knees joint without supporting it. } 22\end{array}$ & $\begin{array}{l}\text { It is located on the back of the tibia bone, } \\
5 \mathrm{~cm} \text { from the lower end of the malleolus. }\end{array}$ \\
\hline Knee joint extension & $\begin{array}{l}\text { Take a sitting position on a chair with a backrest, and place the subject comfortably on the } \\
\text { armrest with both hands. } \\
\text { Using a strap, the pelvis is fixed to the chair, and the feet are not supported, but the hips and } \\
\text { knees are measured at } 90 \text { degrees. } 22\end{array}$ & $\begin{array}{l}\text { It is located on the front side of the tibia bone, } \\
5 \mathrm{~cm} \text { from the lower end of the malleolus }\end{array}$ \\
\hline
\end{tabular}


의 측정자 간 신뢰도는 $\mathrm{ICC}=0.98$ 로 보고 되었다. ${ }^{25}$

\section{(4) 일어서서 걷기 검사(timed up and go test, TUG)}

일어서서 걷기 검사(timed up and goo test, TUG)는 노인의 기능적 운 동성(functional mobility)을 측정할 수 있는 검사 방법이다. ${ }^{26}$ 모든 대 상자는 동일한 기준점에서 보행기(walker)를 사용하여 검사자의 감 독 하에 독립적인 보행을 하였으며 팔걸이가 있는 의자로 높이 $46 \mathrm{~cm}$ 의 의자를 놓고 앉은 다음 시작'이라는 구령에 따라 의자에서 일어나 서 앞쪽 $3 \mathrm{~m}$ 지점까지 보행한 후 비 수술 측 방향으로 돌아와 가능한 빠르고 안전하게 다시 의자에 앉은 동작을 측정하였다. 초기 연습 시 험은 2 회 시험 시행하고 시험 사이 1 분간의 휴식을 가졌다. 총 3 회를 측정하여 평균값을 사용하며, 중재 전과 후의 검사는 동일한 조건에 서 시행하였다. TUG 검사의 측정자 내 신뢰도는 $r=0.99$ 이고, 측정자 간 신뢰도는 $r=0.98$ 로 높은 수준의 신뢰도를 가진 평가 도구이다. ${ }^{26}$

(5) 시각적 사상 척도(visual analogue scale, VAS)

연구 대상자의 엉덩관절 통증은 주관적 수준을 평가하기 위해 임상
에서 광범위하게 사용되는 $10 \mathrm{~cm}$ 시각적 사상 척도(visual analog scale, $\mathrm{VAS}$ )를 사용하여 평가하였다. 시각적 사상 척도는 통증의 정도 측정 에 가장 일반적으로 사용되는 평가 척도이며 타당성이 있는 평가 도 구로, 직선의 왼쪽 끝에 숫자 0 으로 통증이 없는 상태, 그리고 오른쪽 으로 갈수록 통증의 정도가 심해지고 오른쪽 끝 숫자 10에 도달하면 참을 수 없는 정도의 최대 통증 상태로 정의하였다. 시각적 사상 척도 의 측정자 간 신뢰도는 $r=0.95$ 로 높은 수준의 신뢰도를 가진 평가 도 구이다.27

\section{3) 자료분석}

본 연구의 자료처리는 SPSS for Window ver. 21.0을 이용하여 통계분 석을 실시하였다. 모든 항목의 각 변인들에 대한 측정값을 평균 (mean, M)과 표준편차(standard deviation, SD)로 산출하여 비교하였 다. 모든 대상자의 일반적 특성은 빈도 분석을 실시하였고, 측정 시점 에 대한 값들의 변화량에 대한 집단 내 차이는 프리드만 검정(Friedman test)을 실시하였고, 집단 간 차이는 반복 측정 분산분석(repeated measured ANOVA)을 사용하였다. 본 연구의 가설검정을 위한 통계학

Table 3. General characteristics of subject

$(n=25)$

\begin{tabular}{|c|c|c|c|c|}
\hline Variable & & experimental group $(n=13)$ & control group $(n=12)$ & $\mathrm{p}$-value \\
\hline \multirow[t]{2}{*}{$\operatorname{Sex}(\%)$} & Male & $2(15.38 \%)$ & $2(16.67 \%)^{a}$ & 0.93 \\
\hline & Female & $11(84.61 \%)$ & $10(83.33 \%)$ & \\
\hline Age (years) & & $79.31 \pm 6.74$ & $78.50 \pm 5.42^{\mathrm{b}}$ & 0.748 \\
\hline Height (cm) & & $154.71 \pm 4.38$ & $156.92 \pm 7.83$ & 0.388 \\
\hline Weight (kg) & & $54.60 \pm 5.41$ & $58.70 \pm 6.50$ & 0.099 \\
\hline \multirow[t]{2}{*}{ Diagnosis (\%) } & Femur neck fracture & $7(53.85 \%)$ & $8(66.67 \%)$ & 0.513 \\
\hline & Intertrochanteric fracture & $6(64.15 \%)$ & $4(33.33 \%)$ & \\
\hline K-MMSE (point) & & $26.08 \pm 2.36$ & $26.08 \pm 2.20$ & 0.994 \\
\hline
\end{tabular}

${ }^{\mathrm{a}} \mathrm{N}(\%)$ : number of patients (percentage), ${ }^{\mathrm{b}} \mathrm{Mean} \pm \mathrm{SD}$.

Table 4. Changes in the MFRT, 1OMWT, TUG and VAS within and between groups according to the measurement point

\begin{tabular}{|c|c|c|c|c|c|c|}
\hline & \multirow{2}{*}{ Group } & \multicolumn{4}{|c|}{ Measurement (Mean \pm SD) } & \multirow{2}{*}{$\mathrm{p}$-value } \\
\hline & & Pre & 5th & 10th & 15th & \\
\hline \multirow[t]{3}{*}{ MFRT (cm) } & group I & $8.88 \pm 4.48$ & $11.90 \pm 4.56$ & $14.58 \pm 4.00$ & $15.90 \pm 3.70$ & $0.000^{* *}$ \\
\hline & group II & $10.88 \pm 4.03$ & $11.43 \pm 3.72$ & $12.44 \pm 3.41$ & $12.30 \pm 3.45$ & $0.000^{* *}$ \\
\hline & p-value2 & $0.000^{* *}$ & & & & \\
\hline \multirow[t]{3}{*}{ 10MWT(second) } & group I & $81.44 \pm 22.77$ & $59.14 \pm 20.00$ & $46.11 \pm 12.91$ & $39.94 \pm 11.62$ & $0.000^{* *}$ \\
\hline & group II & $85.89 \pm 21.22$ & $70.73 \pm 20.79$ & $68.03 \pm 19.98$ & $65.28 \pm 28.17$ & $0.000^{* *}$ \\
\hline & p-value2 & $0.009^{* *}$ & & & & \\
\hline \multirow[t]{3}{*}{ TUG (second) } & group I & $92.68 \pm 27.90$ & $61.53 \pm 21.13$ & $50.41 \pm 15.32$ & $42.60 \pm 13.93$ & $0.000^{* *}$ \\
\hline & group II & $81.65 \pm 19.45$ & $69.61 \pm 20.03$ & $67.07 \pm 19.57$ & $65.34 \pm 28.50$ & $0.000^{* *}$ \\
\hline & p-value2 & $0.000^{* *}$ & & & & \\
\hline \multirow[t]{3}{*}{ VAS (score) } & group I & $5.98 \pm 1.05$ & $4.18 \pm 0.75$ & $2.94 \pm 0.91$ & $2.38 \pm 0.96$ & $0.000^{* *}$ \\
\hline & group II & $5.50 \pm 1.51$ & $4.25 \pm 1.29$ & $3.42 \pm 1.24$ & $3.17 \pm 1.19$ & $0.000^{* *}$ \\
\hline & p-value2 & $0.006^{* *}$ & & & & \\
\hline
\end{tabular}

Group I: experiental group, Group II: control group, $\mathrm{p}$-value 1: friedman test within a group for each group, $\mathrm{p}$-value 2: repeated measured ANOVA between group for each group, ${ }^{*} p<0.05,{ }^{* *} p<0.01$. 
Table 5. Contrast test for changes in MFRT, 10MWT, TUG and VAS between two groups at each measurement point

\begin{tabular}{llccc}
\hline & Factor & Type III Sum of Square & F & p-value \\
\hline MFRT & Level2-Level 1 & 38.275 & 12.296 & $0.002^{* *}$ \\
& Level3-Level1 & 107.482 & 25.572 & $0.000^{* *}$ \\
10MWT & Level4-Level1 & 196.058 & 33.564 & $0.000^{* *}$ \\
& Level2-Level 1 & 317.993 & 1.438 & 0.243 \\
& Level3-Level1 & 1906.565 & 8.581 & $0.008^{* *}$ \\
TUG & Level4-Level1 & 2722.92 & 7.78 & $0.010^{*}$ \\
& Level2-Level 1 & 2280.771 & 11.643 & $0.002^{* *}$ \\
VAS & Level3-Level1 & 4786.826 & 18.492 & $0.000^{* *}$ \\
& Level4-Level1 & 7119.581 & 13.643 & $0.001^{* *}$ \\
& Level2-Level 1 & 1.888 & 3.651 & 0.069 \\
& Level3-Level1 & 5.785 & 8.623 & $0.007^{* *}$ \\
\hline
\end{tabular}

Levle1: pre, level 2: 5th, Level 3: 10th, Level 4: 15th, ${ }^{*} \mathrm{p}<0.05,{ }^{* *} \mathrm{p}<0.01$.

Table 6. Changes of the muscle strength of the lower extremity of the surgical side within the group and between the groups at each measurement point

(unit: kg)

\begin{tabular}{|c|c|c|c|c|c|c|}
\hline \multirow{2}{*}{ Strength } & \multirow{2}{*}{ Group } & \multicolumn{4}{|c|}{ Difference of MMT (Mean \pm SD) } & \multirow{2}{*}{$\mathrm{p}$-value 1} \\
\hline & & Pre & 5 th & 10th & 15th & \\
\hline \multirow[t]{3}{*}{ Hip Extension } & Group I & $8.94 \pm 3.12$ & $10.55 \pm 3.54$ & $12.16 \pm 3.20$ & $13.90 \pm 2.97$ & $0.000^{* *}$ \\
\hline & Group II & $7.57 \pm 2.10$ & $8.78 \pm 2.90$ & $9.67 \pm 3.12$ & $9.65 \pm 2.88$ & $0.000^{* *}$ \\
\hline & p-value2 & $0.000^{* *}$ & & & & \\
\hline \multirow[t]{3}{*}{ Hip Abduction } & Group I & $4.43 \pm 1.12$ & $5.22 \pm 1.17$ & $6.00 \pm 1.25$ & $6.01 \pm 1.20$ & $0.000^{* *}$ \\
\hline & Group II & $4.07 \pm 0.86$ & $4.73 \pm 1.08$ & $5.14 \pm 1.21$ & $5.01 \pm 1.42$ & $0.000^{* *}$ \\
\hline & p-value2 & 0.223 & & & & \\
\hline \multirow[t]{3}{*}{ Hip Flexion } & Group I & $3.50 \pm 1.35$ & $4.31 \pm 1.31$ & $4.91 \pm 1.24$ & $5.42 \pm 1.27$ & $0.000^{* *}$ \\
\hline & Group II & $3.27 \pm 0.91$ & $3.79 \pm 1.23$ & $4.40 \pm 0.98$ & $4.45 \pm 1.03$ & $0.000^{* *}$ \\
\hline & p-value2 & 0.076 & & & & \\
\hline \multirow[t]{3}{*}{ Knee Extension } & Group I & $5.45 \pm 2.51$ & $7.04 \pm 2.51$ & $8.30 \pm 2.03$ & $9.01 \pm 2.52$ & $0.000^{* *}$ \\
\hline & Group II & $5.80 \pm 1.85$ & $6.43 \pm 2.02$ & $6.75 \pm 2.37$ & $6.84 \pm 2.51$ & $0.000^{* *}$ \\
\hline & p-value2 & $0.000^{* *}$ & & & & \\
\hline \multirow[t]{3}{*}{ Knee Flexion } & Group I & $4.80 \pm 1.64$ & $6.16 \pm 2.04$ & $6.96 \pm 1.80$ & $7.62 \pm 2.00$ & $0.000^{* *}$ \\
\hline & Group II & $5.04 \pm 0.95$ & $5.43 \pm 0.98$ & $5.84 \pm 1.20$ & $5.74 \pm 1.34$ & $0.000^{* *}$ \\
\hline & p-value2 & $0.000^{* *}$ & & & & \\
\hline
\end{tabular}

Group I: experiental group, Group II: control group, p-value1: friedman test within a group for each group, p-value 2: Repeated measured ANOVA between group for each group, ${ }^{*} p<0.05,{ }^{* *} p<0.01$.

적 유의수준 $(\alpha)$ 은 $\mathrm{p}<0.05$ 로 하였다.

\section{결 과}

\section{1. 연구대상자의 일반적 특성}

연구대상자의 일반적 특성은 다음과 같다. 전체 대상자 28 명 중 실험 도중 3 명이 배제되어 최종 25 명이 실험에 참여하였다. 남성이 4 명이고 여성이 21 명이었다. 수술명에 엉덩관절 목 골절이 15 명이었고, 넙다리 뼈돌기사이 골절이 10 명이었다. 연령은 $78.92 \pm 6.03$ 세이었고, 평균 신 장은 $155.77 \pm 6.23 \mathrm{~cm}$, 평균 체중은 $55.57 \pm 6.20 \mathrm{~kg}$, K-MMSE의 평균값
은 $26.08 \pm 2.20$ 이었다(Table 3 ).

\section{2. 측정시점에 따른 집단 내, 집단 간 MFRT의 변화}

측정 시점에 따른 집단 내, 집단 간 MFRT의 변화에 대한 분석은 다 음과 같은 결과를 나타냈다(Table 4, 5). 실험군은 대조군에 비해 중재 횟수가 증가할수록 더 큰 폭으로 유의하게 증가되는 것으로 나타났 다 $(\mathrm{p}<0.01)$ 측정 시점 별 집단 간 MFRT의 변화에 대한 대비검정에서 모든 시점에서 유의하였으나, 중재 전과 15 회 중재 시점에서 MFRT의 값에서 가장 유의한 변화를 보이는 것으로 나타났다 $(\mathrm{p}<0.01)$. 


\section{3. 측정시점에 따른 집단 내, 집단 간 하지 MMT의 변화}

측정 시점에 따른 집단 내, 집단 간수술 측 하지의 MMT 변화에 대한 분석은 다음과 같은 결과를 나타냈다(Table 6). 하지 엉덩관절 폄근, 무릎 폄근과 굴곡근의 MMT는 실험군에서 대조군에 비하여 중재 횟 수가 증가할수록 더 큰 폭으로 유의하게 증가되는 것으로 나타났다 $(\mathrm{p}<0.01)$. 또한, 측정 시점 별 집단 간 하지 MMT의 변화에 대한 대비 검정에서 모든 시점에서 유의하였으나, 중재 전과 5 회 중재 시점, 중재 전과 10 회 중재 시점까지는 유의한 변화가 없었으나, 중재 전과 15 회 중재 시점에서 엉덩관절 폄근의 근력 변화가 유의한 차이를 보이는 것으로 나타났다 $(\mathrm{p}<0.01)$. 하지만, 엉덩관절 굴곡근과 벌림근의 MMT 변화는 집단 내 변화는 유의하였으나 $(\mathrm{p}<0.01)$, 집단 간 측정 시 점에 따른 근력 변화는 실험군에서 더 큰 폭으로 증가되었으나 집단 간에는 유의하지 않게 나타났다.

\section{4. 측정시점에 따른 집단 내, 집단 간 $10 \mathrm{MWT}$ 의 변화}

측정 시점에 따른 집단 내, 집단 간 $10 \mathrm{MWT}$ 의 변화에 대한 분석은 다 음과 같은 결과를 나타냈다(Table 4, 5). 실험군에서 대조군에 비하여 중재 횟수가 증가할수록 평균 $10 \mathrm{MWT}$ 는 감소되었고 통계적으로 유 의하였다 $(\mathrm{p}<0.01)$ 측정 시점 별 집단 간 $10 \mathrm{MWT}$ 의 변화에 대한 대비 검정에서 중재 전과 5 회 중재 시점에서는 유의한 차이가 없었으나, 중 재 전과 10 회 중재 시점, 중재 전과 15 회 중재 시점에서는 $10 \mathrm{MWT}$ 가 유의한 차이를 보이는 것으로 나타났다 $(\mathrm{p}<0.01)$.

\section{5. 측정시점에 따른 집단 내, 집단 간 TUG의 변화}

측정 시점에 따른 집단 내, 집단 간 $\mathrm{TUG}$ 의 변화에 대한 분석은 다음 과 같은 결과를 나타냈다(Table 4, 5). 실험군에서 대조군에 비하여 중 재 횟수가 증가할수록 평균 TUG는 감소되었고 통계적으로 유의하 였다 $(\mathrm{p}<0.01)$. 측정 시점 별 집단 간 TUG 변화에 대한 대비검정에서 모든 시점에서 유의하였으나, 중재 전과 15 회 중재 시점에서 TUG 변 화가 가장 유의한 변화를 보이는 것으로 나타났다 $(\mathrm{p}<0.01)$.

\section{6. 측정시점에 따른 집단 내, 집단 간 VAS의 변화}

측정 시점에 따른 집단 내, 집단 간 VAS의 변화에 대한 분석은 다음 과 같은 결과를 나타냈다(Table 4, 5). 실험군에서 대조군에 비하여 중 재 횟수가 증가할수록 평균 VAS는 감소되었고 통계적으로 유의하였 다 $(\mathrm{p}<0.01)$ 측정 시점 별 집단 간 수술 측 $\mathrm{VAS}$ 의 변화에 대한 대비검 정에서 중재 전과 5 회 중재 시점에서는 유의한 차이가 없었지만, 중재 전과 10 회 중재 시점, 중재 전과 15 회 중재 시점에서는 VAS의 변화가 유의한 차이를 보이는 것으로 나타났다 $(\mathrm{p}<0.05)$.
고 찰

우리는 양극성 인공관절 부분치환술 후 체간보정재활로봇 훈련을 했을 때 환자의 동적 균형, 하지 근력, 보행 능력 및 통증에 미치는 효 과를 알아보고자 실시하였다. 본 연구에서 시각적 바이오피드백을 기반으로 한 체간보정재활로봇 훈련의 연구결과 측정 시점에 따른 집단 내, 집단 간 동적 균형 검사를 위한 수정된 기능적 팔 뻗기 검사 (MFRT)에서 실험군 중재 횟수가 증가할수록 동적 균형의 증가를 보 였다. 체간 훈련 운동(trunk training exercise)은 뇌졸중 후 체간 수행 과 앉은 자세의 균형 향상뿐만 아니라 선 상태의 균형과 보행의 향상 으로 이어진다고 하였다. ${ }^{28}$ 본 연구에서 체간보정재활로봇 훈련은 양 발을 고정한 상태에서 반복적인 좌 · 우 체중이동과 앉았다 일어서 기를 함으로써 체간의 전 · 후, 좌 · 우 자세 조절 능력을 향상시킬 수 있었으며 이러한 체간의 자세 조절 능력의 향상이 동적 균형 능력을 향상했다는 이전 연구 결과는 본 연구의 결과와 일치한다. ${ }^{28}$ 그러므 로 체간보정재활로봇 훈련의 앉았다 일어서기(sit to stand, STS) 운동 적용으로 항중력에 대한 체간의 자세 조절 향상과 엉덩관절 및 발목 전략의 안정성 향상으로 동적 균형의 개선을 보였다고 사료된다.

본 연구 결과 측정 시점에 따른 집단 내 하지 근력은 엉덩관절과 무 릎관절 폄근, 무릎 굽힘근에서 근력 향상이 두드러지게 나타냈으며, Sylliaas 등 29 와 Miura 등 ${ }^{9}$ 의 하지 폄 운동과 STS 훈련은 하지의 근력 강화 개선에 효과적이라고 하였으며, 9,29 이것은 본 연구 결과와 일치 한다. Tsukagoshi 등 30 은 인공 엉덩관절 전치환술 후 6개월 이상 된 여 성 환자의 체중지지 운동과 비체중지지 운동을 통해 체중지지 그룹 에서 넙다리네갈래근의 두께가 증가됨을 보고 하였다. Miura 등은 42 명의 인공 엉덩관절 전치환술 후 앉았다 일어서기(sit to stand) 중재 의 근력 강화는 수술 측 하지의 지면 반발력과 체중지지의 향상을 보 고 하였다. 이전 연구에서 앉았다 일어서기(sit to stand) 중재로 수술 측 하지의 지면 반발력과 체중지지의 향상을 보고 하였으며, 체중지 지 운동을 통하여 넙다리네갈래근의 두께 증가를 보고하였다. 엉덩 관절벌림근과 굽힘근의 근력 변화에 유의한 차이가 없었음에도 불 구하고 체간보정재활로봇 훈련은 특히, 넙다리네갈래근과 큰볼기근 근력 향상에 효과적이었으며 이것은 하지의 대칭적인 체중지지가 수 술 측 하지의 근력 및 안정성의 향상을 나타낸 것으로 사료된다.

본 연구결과 측정 시점에 따른 집단 내, 집단 간 $10 \mathrm{MW}$ 과 TUG의 변화는 실험군에서 중재 횟수가 증가할수록 보행 시간의 감소로 기 능적 보행 능력 향상을 보였다. 선행 연구에서 노인 환자를 대상으로 한 로봇-보조 균형 운동은 동적 균형능력과 하지 근력 및 보행 속도 (TUG) 향상의 효과를 보고하였고, 이것은 불안정한 보행을 개선한 다고 하였다. ${ }^{31} \mathrm{Eom}$ 은 ${ }^{32}$ 엉덩관절 전치환술 환자를 대상으로 2주간 근력 운동프로그램을 적용하여 보행거리의 향상을 보고 하였고, ${ }^{32}$ 
인공 엉덩관절 전치환술 후 급성기 동안 무릎관절 폄근에 대한 점진 적 근력운동으로 근력의 향상과 $10 \mathrm{MW}, \mathrm{TUG}$ 및 6 분 보행의 개선을 보고하였다.3334 또 다른 연구에서 엉덩관절 골절 수술 환자에서 엉덩 관절과 무릎관절 폄 근력은 보행 속도와 계단 오르기 시간 등을 결정 하는 중요한 요인이라고 하였다. ${ }^{35}$ 본 연구결과 체간보정재활로봇 훈 련은 하지의 근력 향상뿐만 아니라 균형 및 기능적 보행 능력의 향상 에도 영향을 준 것으로 나타났으며, 이러한 결과는 하지의 근력 향상 이 보행 시 균형과 보행 속도, 보행 거리를 증가시키는데 효과적이며, Kronborg 등 ${ }^{33}$ 의 선행 연구와 일치한다. 또한, 본 연구에서 체간보정 재활로봇 훈련은 닫힌 사슬 운동(closed kinetic chain, $\mathrm{CKC}$ )에서 단계 적인 엉덩관절과 무릎관절의 기계적 압박을 통하여 고유수용성 감 각을 향상시켰을 것으로 생각되며 이것은 자세 조절 능력과 보행 능 력에 영향을 끼쳤을 것으로 생각된다.

본 연구결과 측정 시점에 따른 집단 내, 집단 간 VAS는 실험군에서 중재 횟수가 증가할수록 통증의 감소를 보였으며 통계적으로 유의하 였다. 이전 연구에서 인공관절 전치환술 환자의 수술 후 조직 손상은 외측 허벅지 통증을 주로 호소하였으며, 이러한 통증은 수동적 혹은 능동적 움직임의 제한을 가져오며, ${ }^{36,37}$ 이를 방치할 때 장기간의 정서 적 및 심리적 고통의 유발과 만성통증으로 이어질 수 있다.38,39 인공관 절 전치환술 환자에 대한 물리치료 중재 연구에서 엉덩관절 폄근, 굽 힘근, 벌림근 및 무릎관절 폄근에 4주간 점진적 저항 훈련을 통해서 체중지지와 통증과의 상관관계를 보였으며, Overgaard 등 ${ }^{34}$ 와 Hoeks$\mathrm{ma}$ 등 40 은 엉덩관절 골관절염 환자의 관절 가동범위 증가는 통증의 감소로 이어진다고 하였다. ${ }^{40}$ 이러한 하지의 근력 강화와 체중지지뿐 만 아니라 관절 가동범위의 증가는 통증 감소에 효과적이라는 이전 의 선행 연구와 일치한다. 따라서 수술로 인한 엉덩관절의 통증은 움 직임과 운동을 회피하려 하며, 관절가동범위의 제한과 하지의 비사 용(disuse) 등으로 인하여 엉덩관절과 하지의 근력 약화와 관절의 안 정성이 떨어져 보행에 어려움을 갖게 되므로 본 연구에서 체간보정 재활 로봇의 일관성 있는 반복적인 하지의 근력강화 운동은 관절가 동범위의 증가, 유착의 감소와 근력강화를 촉진하여 통증 감소에 긍 정적인 영향을 주었을 것으로 사료된다.

\section{REFERENCE}

1. WHO. Falls. WHO media center. 2017.

2. Canale ST, Beaty JH. Campbell's operative orthopaedics. 11th ed. Philadelpia, Mosby, 2008:270-343

3. Park C, Ha YC, Jang S et al. The incidence and residual lifetime risk of osteoporosis-related fractures in Korea. J Bone Miner Metab. 2011; 29(6):744-51.

4. Sathiyakumar V, Greenberg SE, Molina CS et al. Hip fractures are risky business: an analysis of the NSQIP data. Injury. 2015;46(4):703-8.
5. National clinical cuideline centre. The management of hip fracture in adults. London, Royal college of physicians, 2011.

6. Foucher KC, Hurwitz DE, Wimmer MA. Preoperative gait adaptations persist one year after surgery in clinically well-functioning total hip replacement patients. J Biomech. 2007;40(15):3432-7.

7. Talis VL, Grishin AA, Solopova IA, et al. Asymmetric leg loading during sit-to-stand, walking and quiet standing in patients after unilateral total hip replacement surgery. Clin Biomechanics, 2008;23(4):424-33.

8. Tsaklis PV, Grooten WJ, Franzen E. Effects of weight shift training on balance control and weight distribution in chronic stroke: A pilot study. Top Stroke Rehabil. 2012;19(1):23-31.

9. Miura N, Tagomori K, Ikutomo H et al. Asymmetrical loading during sit-to-stand movement in patients 1 year after total hip arthroplasty. Clinical Biomechanics. 2018;57:89-92.

10. Sumayeh B, Adam T. Marmon, Federico Pozzi et al. Sit-to-stand biomechanics before and after total hip arthroplasty, 2015;30(11):2027-33

11. Abujaber S, Pozzi F, Zeni J. Influence of weight bearing visual feedback on movement symmetry during sit to stand task. Clinical Biomechanics, 2017;47:110-6.

12. Jee KY, Kim YJ. The trends and visions of medical robotics market in the IT-BT convergence, Electronics and relecommunications trend, 2008; 23(2):119-29.

13. Butler DP, Willett K. Wii-rehabilitation: is there a role in trauma. Injury. 2010;41(9):883-5.

14. Haruyama K, Kawakami M, Otsuka T. Effect of core stability training on trunk function, standing balance and mobility in stroke patients. Neurorehabilitation and Neural Repair. 2016;31(3):240-9.

15. Kwakkel G, Kollen B. Predicting activities after stroke: what is clinically relevant. International Journal of Stroke. 2013;8(1):25-32.

16. Belas dos Santos M, Barros de Oliveira C, Dos Santos A et al. A Comparative Study of conventional physiotherapy versus robot-assisted gait training associated to physiotherapy in individuals with ataxia after stroke. Behavioural Neurology, 2018:2892065.

17. Rampazo-Lacativa MK, D’Elboux MJ. Effect of cycle ergometer and conventional exercises on rehabilitation of older patients with total hip arthroplasty: study protocol for randomized controlled trials. Trials, 2015;16(1):135

18. Patrick JM. Total hip replacement exercise guide, AAOS, 2007

19. Oshita K, Yano S. The effect of light gripping acane on the dynamic balance control, Open Biomed Eng J. 2015;23(9):146-50

20. Bohannon RW, Andrews AW. Interrater reliability of hand-held dynamometry. Phys Ther. 1987;67(6):931-3.

21. McMahon LM, Burdett RG, Whitney SL. Effects of muscle group and placement site on reliability of hand-held dynamometry strength measurements. J Orthop Sports Phys Ther. 1992;15(5):236-42.

22. Crompton J, Galea MP, Phillips B. Hand-held dynamometry for muscle strength measurement in children with cerebral palsy. Dev Med Child Neurol. 2007;49(2):106-11.

23. Schache MB, McClelland JA, Webster KE. Reliability of measuring hip abductor strength following total knee arthroplasty using a hand-held dynamometer. Disabil Rehabil. 2016;38(6):567-600.

24. Suetta C, Aagaard P, Rosted A et al. Training-induced changes in muscle CSA, muscle strength, EMG, and rate of force development in elderly subjects after long-term unilateral disuse. J Appl Physiol. 2004;97(5):1954-61. 
25. Vernon S, Paterson K, Bower K et al. Quantifying individual components of the TUG using the kinect in people living with stroke. Neurorehabilitation Neural Repair. 2015;29(1):48-53.

26. Podsigadlo D, Richardson S. The timed "up \& go": a test of basic functional mobility for frail elderly persons. J Am Geriatr Soc. 1991;39(2): 142-8.

27. Bijur PE, Latimer CT, Gallagher EJ. Validation of a verbally administered numerical rating scale of acute pain for use in the emergency department. Acad Emerg Med. 2003;10(4):390-2.

28. Cabanas Vald's R, Cuchi GU, Bagur Calafat C. Trunk training exercises approaches for improving trunk performance and functional sitting balance in patients with stroke: a systematic review. Neurorehabilitation. 2013;33(4):575-92.

29. Sylliaas H, Brovold T, Wyller TB et al. Progressive strength training in older patients after hip fracture: a randomised controlled trial. Age Ageing. 2011;40(2):221-7.

30. Tsukagoshi R, Tateuchi H, Fukmoto Y et al. Functional performance of female patients more than 6 months after total hip arthroplasty shows greater improvement with weight-bearing exercise than with non-weight-bearing exercise. Randomized controlled. Eur J Phys Rehabil Med. 2014;50(6):66575.

31. Ozaki K, Kondo I, Hiran S et al. Training with a balance exercise assist robot is more effective than conventional training for frail older adults. Geriatr Gerontol Int. 2017;17(11):1982-90.

32. Eom SB. A study on the effect of exercise training program on the function of a total hip in a patient with a total hip replacement after a surgery.
Kangwon National University. Dissertation of Master's Degree. 2008.

33. Kronborg L, Bandholm T, Palm H et al. Effectiveness of acute in-hospital physiotherapy with knee-extension strength training in reducing strength deficits in patients with a hip fracture: a randomised controlled trial. Plos One. 2017;12(6):e0179867.

34. Overgaard J, Kristensen MT. Feasibility of progressive strength training shortly after hip fracture surgery. World J Orthop. 2013;4(4):248-58.

35. Lamb SE, Morse RE, Evans JG. Mobility after proximal femoral fracture: the relevance of leg extensor power, postural sway and other factors. Age Ageing. 1995;24(4):308-14.

36. Lavernia C, D’apuzzo M, Hernandez VH et al. Patient-perceived outcomes in thigh pain after primary arthroplasty of the hip. Clin Orthop Relat Res. 2005;441:268-73.

37. Kerr DR, Kohan L. Local infiltration analgesia: a technique for the control of acute postoperative pain following knee and hip surgery: A case study of 325 patients. Acta Orthopaedica. 2008;79(2):174-83.

38. Erlenwein J, Muller M, Falla D et al. Clinical relevance of persistent postoperative pain after total hip replacement-a prospective observational cohort study. J Pain Res. 2017;10:2183-93.

39. Meissner W, Coluzzi F, Fletcher D et al. Improving the management of post-operative acute pain: priorities for change. Curr Med Res Opin. 2015;31(11):2131-43.

40. Hoeksma HL, Dekker J, Ronday HK et al. Comparisson of manual therapy and exercise therapy in osteoathritis of the hip: A randomized clinical trial. Arthritis Rheum. 2004;51(5):722-9. 